\title{
EXPERT WRITING:
}

\section{SCAFFOLDING INFORMATIONAL WRITING USING FAMILIAR TOPICS}

\author{
Darlene Young Grove
}

\begin{abstract}
This article describes Expert Writing, a strategy to support English language learners and others in organization and idea development in informational writing. English language learners often struggle with idea development, because they lack sufficient vocabulary to construct expanded sentences and paragraphs. Expert Writing enables students to draw on topics they already know well in order to develop an informational writing piece. Students choose a topic on which they consider themselves "experts" and then "teach" about their topic to peers. This oral rehearsal gives students an audience and encourages them to think about questions a reader might have. During this step, students develop "important ideas" about the topic, which help students structure their writing as main ideas that are developed into paragraphs. Students also create "glossary words," which become a roadmap for organizing paragraphs around the main idea.
\end{abstract}

KEYWORDS: English language learner; idea development; informational writing, oral rehearsal

\section{Background}

When students are learning English, they often develop listening, speaking, and reading skills before writing. In many cases, writing is the last domain in which students reach fluency. According to Dangling Fu in Writing between languages: how English language learners make the transition to fluency, grades 4-12, "When English language learners write in English, they are thinking in a limited or less-fluent language, which results in thought

\footnotetext{
* Teacher at Jefferson County Public Schools.
} 
blocks. That is why nonnative speakers say that when they write in English, it seems that nothing comes to mind; their minds are 'completely blank"' (2009, p. 13).

In working with English language learners on informational writing, I noticed that one of two things usually happened: either students had trouble with idea development and wrote very little, or they copied word-for-word whole sentences and paragraphs from informational texts. In addition, students might look in books to gather information about animals or tornadoes, for example, but would get overwhelmed with facts and be unable to sort them into an organized writing piece. Structuring an informational writing piece seemed an insurmountable task. Even if they generated a list of questions ahead of time in attempt to focus their research, they would often not find the answers they sought or merely end up with a list of copied facts and no idea how to group them into subtopics.

Fu suggests starting with what students can already do. Similarly, Lucy Calkins in If - then —curriculum: assessment-based instruction, grade 4, suggests teaching structure in informational writing by framing it in "something known and familiar" (2013, p. 21). Rather than have students gather facts to use in informational writing only to get bogged down as described above, allow them to write about something they already know. "To keep writers' full focus on the organization and structure of the information genre, therefore, you'll want to ensure that they choose topics that feel accessible, easy, and familiar. To this end, you'll want to issue an invitation to write about something they are experts on-a topic on which they are an authority" (Calkins, 2013, p. 21).

Expert Writing enables English language learners to tap into their resources of background knowledge. Students can always think of something they are an authority on, whether it's soccer, babysitting, cooking, gaming, or styling hair. Each student comes with knowledge that can be used as a scaffold for idea development and organization. This strategy is adapted from Calkins' work (2013). It draws on oral rehearsal and gives students a headstart on idea development. According to Calkins, the use of oral rehearsal gives students "an immediate, very real audience" (2013, p. 21). Writing about "expert topics" allows students to focus on the structure of their writing. In addition, I found that when students 
were given the opportunity to write on topics they understood and had a passion for, their enthusiasm for writing was incredible. While working with students on the strategy, I was frequently greeted at the classroom door with "Do we get to write today?" Some students even with very limited English developed their pieces with details, and some went beyond what I had asked of them and continued writing on their own.

\section{The Expert Writing Process}

In using the Expert Writing Strategy, students go through five basic steps:

1. Brainstorming possible topics and choosing a topic they're experts at

2. Engaging in oral rehearsal to develop their topic with important things and glossary words

3. Defining glossary words in their own words

4. Constructing paragraphs using partner sentences

5. "Stacking" the paragraphs into an informational writing piece.

In the first step, students brainstorm a list of topics they think they might be experts at. I tell them it's important to think about something they know well enough that they could teach someone else all about it. I model this for them with a think-aloud using the overhead projector or document camera so students can see my list as I write down topics I think I might be an expert at. For example, I tell students that I'm pretty good at cooking, because I cook dinner for my family almost every night, and I've been doing it for many years. I write "cooking" on my list. Another thing I think I know a lot about is teaching, I tell them. "I'm a teacher, so of course I know how to do that. I think I could teach someone else about it," and I write "teaching" on my list. I continue to model the brainstorming by adding another topic. "I know something else I think I'm an expert at," I say. "Dogs! I have two dogs, and I've owned dogs most of my life. I know how to take care of them, and I'm pretty sure I could teach someone all about dogs." I add "dogs" to my list.

In the next step, students use oral rehearsal to "teach" one of their topics to someone else. In this stage, students will be able to revise their thinking as they go, as they answer 
their partners' questions, or as they discover that they don't have as much expertise on a topic as they thought. I group students in pairs or small groups and tell them to think of three important things their partner/s needs to know about their topic. These important things will become the main ideas for their paragraphs. Before they get started, I explain that as they teach their topics, it's crucial that they think about some special words that their partners might not know since they are not an expert on the subject. This step is key in helping students develop their ideas and determining if students actually have enough knowledge on a topic to write an expert paper about it. I instruct students to choose one or more of the topics they brainstormed and teach it, using important things and glossary words. If they can't think of special words, or glossary words, then they might not be an expert and should try another topic.

Again, I model the step for them before they get started. In this step, the think-aloud lets students see the process I go through to arrive at the topic that I think is the best choice for me to write about. I choose to start with teaching about cooking. I hold up three fingers and start to count off three important things about cooking. "Let's see. If I'm going to teach someone about cooking, I think I need to teach them about what kinds of foods you can cook," I say. I hold up my next finger and say, "another thing would be what you need to cook with. I'll call that 'equipment.' Also, I think it's pretty important to be safe when you cook. I was teaching my children how to cook, and I made sure I showed them how to hold knives properly and how to keep yourself from getting burned, so I think I could call that 'safety' in the kitchen." For glossary words, I return to each important thing. For the kinds of things you can cook, I explain that I could talk about the different types of foods like Mexican, Italian, etc. I could call those 'cuisines.' ''Cuisines' could be one of my glossary words," I tell them, but then I have a little trouble thinking of another glossary word for that important thing. “I could say 'Mexican' or 'Italian' could possibly be glossary words, but a lot of people already know what those are." Maybe I could do better with a different topic, I tell them. 'You know, I think I know a lot about cooking, but I'm going to try talking about dogs and see if I like that topic better." I choose three important things: where to get a 
dog, how to take care of a dog, and types of dogs. For glossary words, I choose 'rescue organization,' 'shelter,' and 'breeder' for my first important thing. Under "how to take care of a dog,"' my glossary words are 'vaccinations,' 'crate,' and 'rewards.' For types of dogs, my glossary wrods are: 'mutt,' 'purebreed' and 'show dog'. Since I was able to think of three glossary words for each important thing, I announce to the class that I am going to choose that topic. I fill out my Important Things graphic organizer (Figure 1).

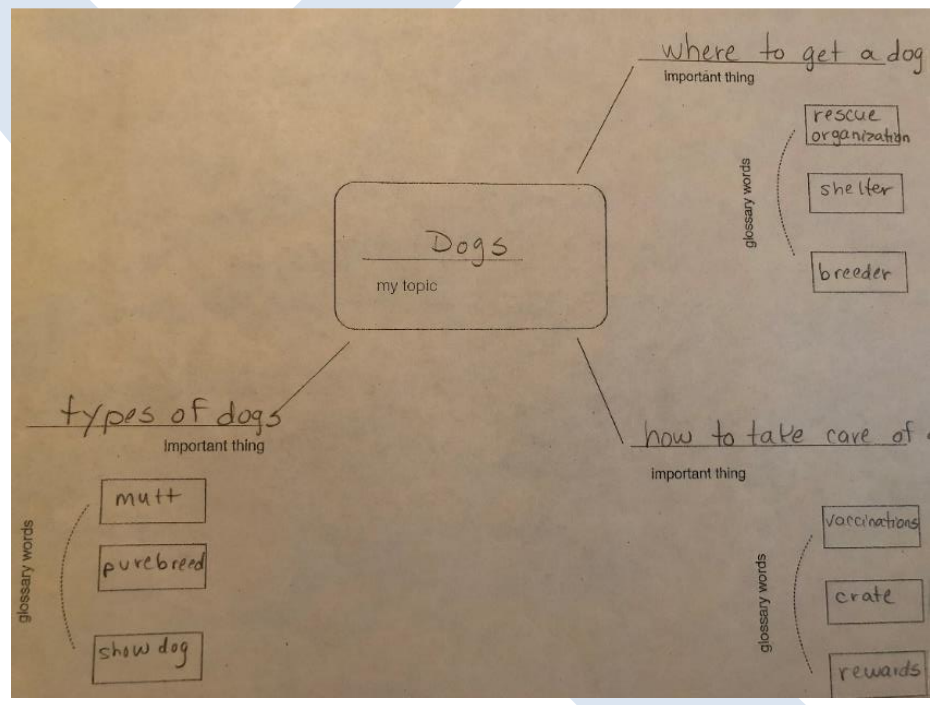

Figure 1

Students then engage in their own rehearsal with partners and determine their important things and glossary words and complete their organizers.

After I've decided on my important things and glossary words, I next model how to complete the Glossary Word organizer. I copy all of my glossary words onto the organizer and then write a definition for each one in my own words. For example, for 'rescue organization,' I say, "a group of people who work together to try to find homes for dogs that don't have 
owners" (Figure 2). Students should complete their Glossary Word organizer with their own definitions.

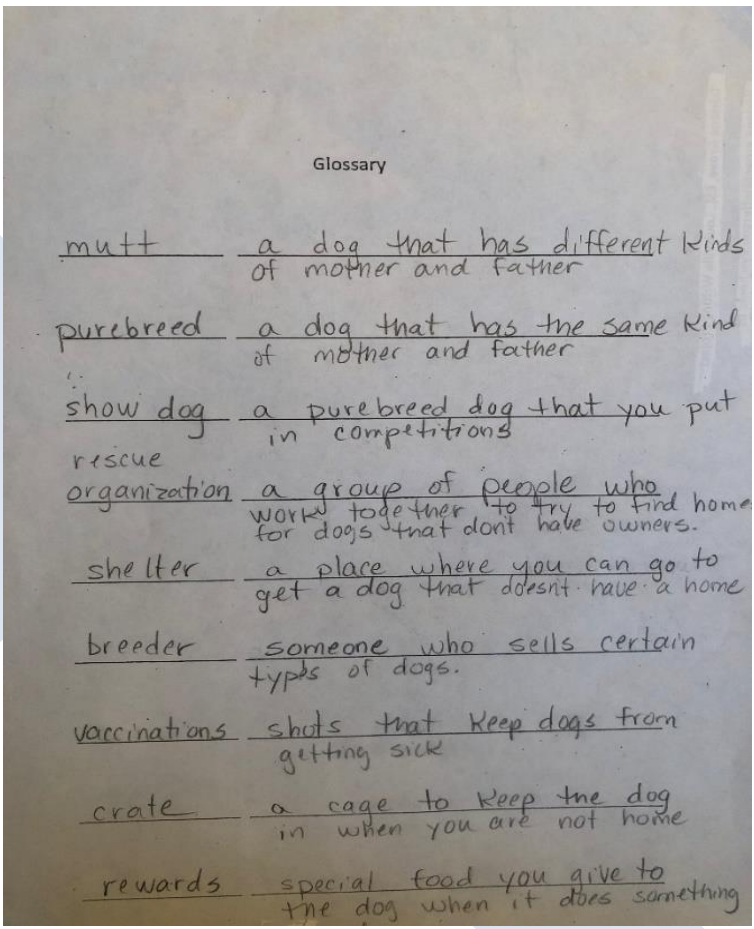

Figure 2

Next, students will use their glossary words to write partner sentences: two sentences that go together. In general, the first sentence comes from the definition, and the second sentence should give more information. For example, I model partner sentences for 'rescue organization.' I take the first sentence almost directly from the Glossary Word organizer: "A rescue organization is a group of people who work together to try to find homes for dogs that don't have owners." For the partner sentence, I expand on that: "A lot of rescue organizations specialize in finding homes for certain types of dogs, such as Great Danes or 
golden retrievers" (Figure 3). Each completed Partner Sentences graphic organizer will become one paragraph.

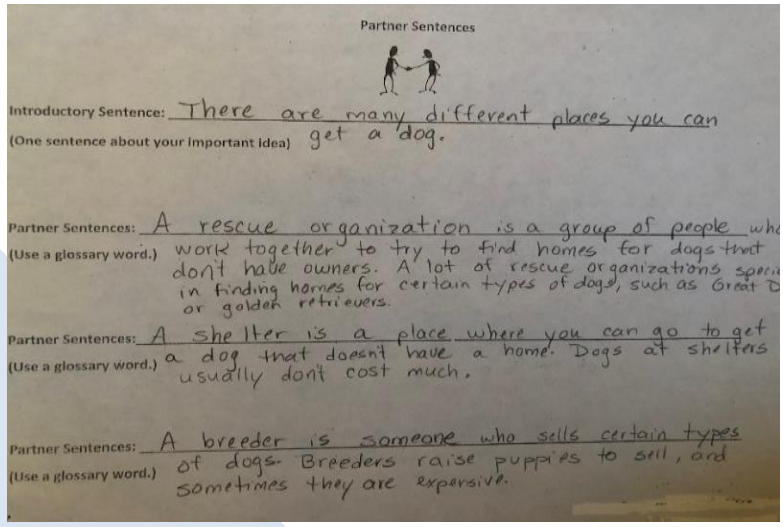

Figure 3

The final step in Expert Writing is to "stack" the paragraphs into a draft. Students write an introductory sentence using the Important Things organizer as a map. To model this, I write one sentence about my topic and then add a sentence that includes each "important thing." For example, "Dogs make great pets. If you're thinking of getting one, you'll need to know about types of dogs, where to get a dog, and how to take care of a dog." The Partner Sentences organizers contain the sentences that will form the next three paragraphs. Students will transfer what they've written to their drafts.

Using Expert Writing with Students of Different Levels of English Language Proficiency

Expert Writing is a flexible strategy that can be adapted for use with students at different levels of English language development. In this section, I'll describe the process as it was used with two English language learners.

K.M. 
K.M. is a 10-year-old beginning level English learner, who first entered a U.S. school a few months before using the Expert Writing strategy. K.M's native language is Kinyarwanda, and she received no instruction in English before arriving in the U.S. and beginning $4^{\text {th }}$ grade. She uses mostly single words or simple phrases and gestures to communicate. She has good letter-sound knowledge and can hear and write many phonemes in spoken English. In addition, she can read and write some sight words. Accommodations that were used with K.M. were prompting, sentence frames, use of online translator, drawing, and scribing. The Expert Writing process with K.M. took place over several weeks with writing once or twice or week for 30 minutes at a time.

I went through modeling the brainstorming process with K.M. and some other students from her class and asked them to think about what they were experts on and brainstorm a list of possible topics. K.M. struggled with this activity. K.M.'s ESL teacher knew, based on previous interactions, that K.M. had a lot of knowledge on how to style her hair in a variety of ways. Rather than have K.M. brainstorm a list of possible topics, I asked K.M. if she would like to write about how to style hair since she knew so much about that. She nodded that she would. I asked K.M. if she could think of some ways to style hair. I used gestures to indicate different hairstyles. "How do you style your hair? Can you tell me?” I asked. She hesitated and seemed to be mentally groping for words, so I offered, "Can you draw me a picture of how you style your hair?" and handed her a piece of paper and pencil. A few minutes later, K.M. had produced two drawings: one showed long hair and another with short hair, which were natural and straight hair (Figure 4 ). I commented that sometimes she wore her hair in braids and asked if that could be a hairstyle to write about. She agreed and completed her Important Things organizer with "natural," "straight," and braids" (Figure 5). 


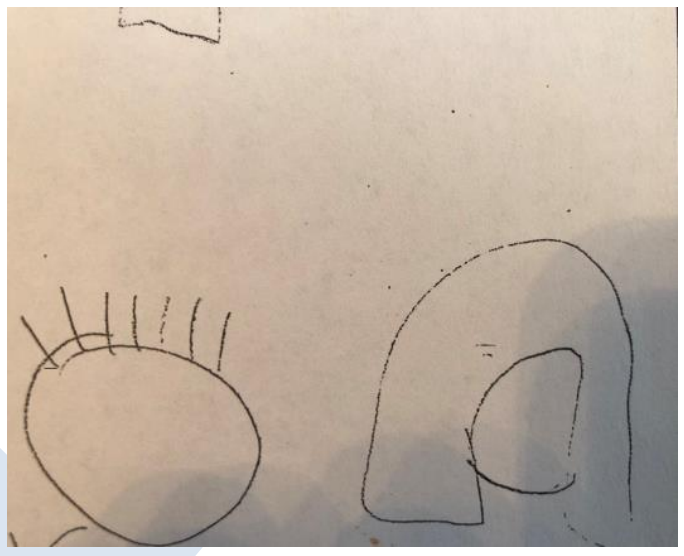

Figure 4

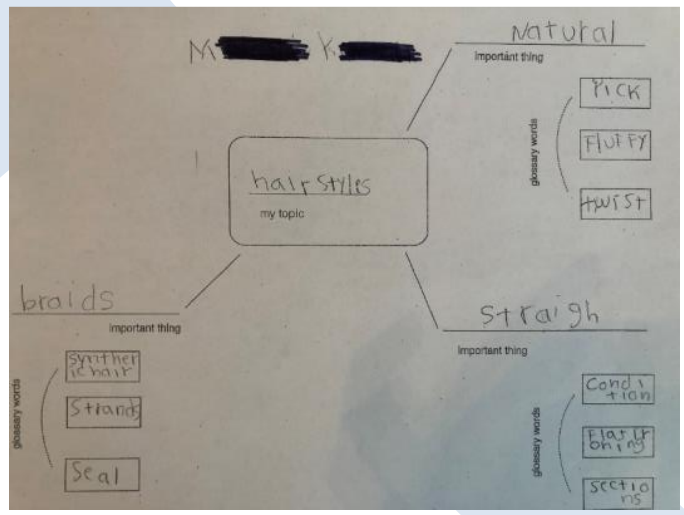

Figure 5

As I worked with K.M. to complete her Important Things organizer, she often groped for words, but I was confident she knew the concepts; she merely lacked the English vocabulary, so I decided to do some Internet searches to find the images and terms for things she described to me. For example, when describing braids, she communicated through a combination of gestures and phrases that braiding required extra hair that could be interwoven into the braid. I did an Internet search, using "hair for braiding" and found pages of "synthetic hair," which K.M. confirmed was the extra hair used in braiding. "Synthetic hair" became another of her glossary words. When describing how to style straight hair, 
K.M. originally wrote "flat ironing," because someone had suggested that term to her, but she changed to "paddle brush" when she began her partner sentences after Internet searches brought up images of that tool.

I used scaffolding and prompting to help K.M. complete her Glossary Word organizer (Figure 6). She also drew some pictures to express her thoughts. For example, she drew a picture to illustrate the word 'fluffy' (Figure 7). As she used gestures and phrases, I often recast what she said to provide a model for her, which she repeated and wrote on her organizer. For the Partner Sentences organizer (Figure 8 [a, b, c]), I often provided sentence frames. For example, I gave her the following frames "Another way to wear your is ...;" "To make braids, you need...;" and "The last thing you do is...." For each of these, she completed the sentence orally. I then recited the entire sentence to her, which she repeated and wrote on her organizer. She then wrote her draft (Figure 9 [a, b]) using her completed organizers.

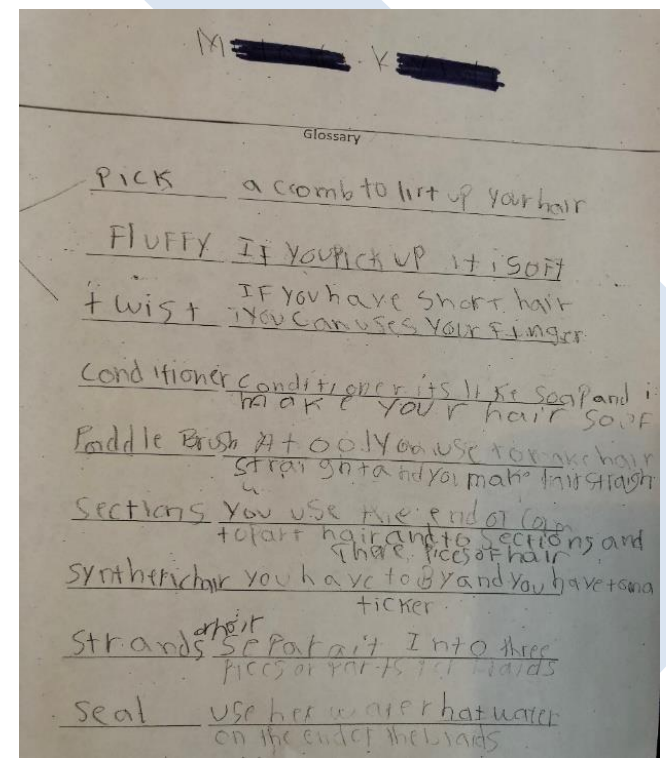

Figure 6 


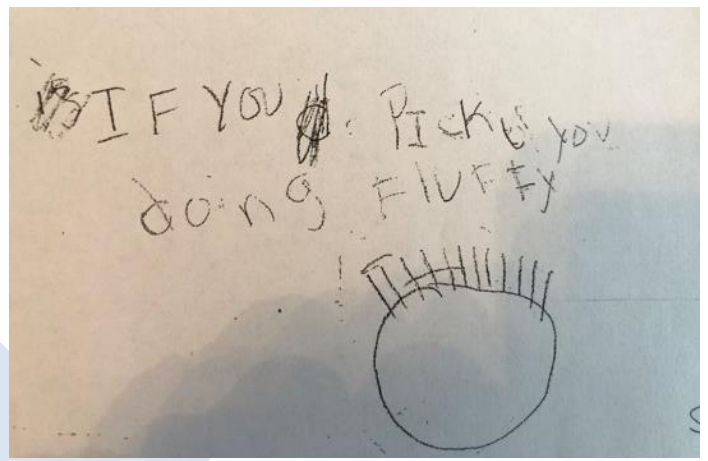

Figure 7

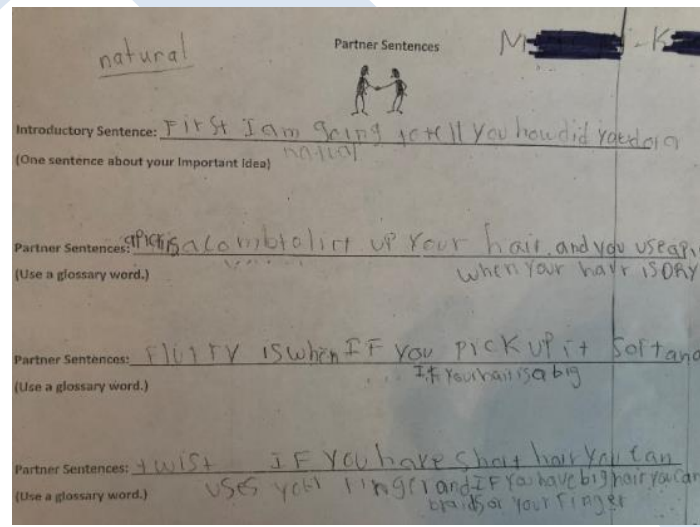

Figure 8 (a) 


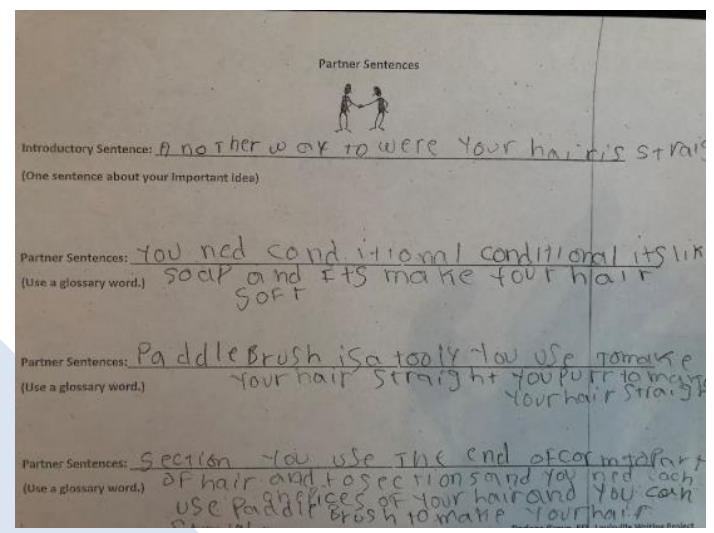

Figure 8 (b)

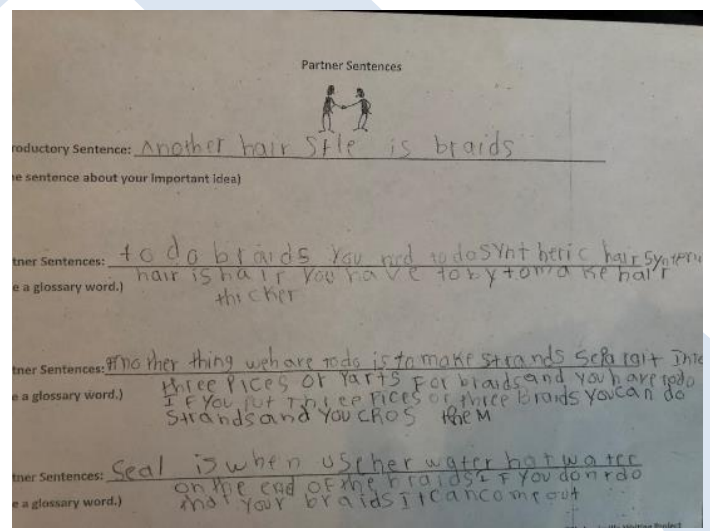

Figure 8 (c) 


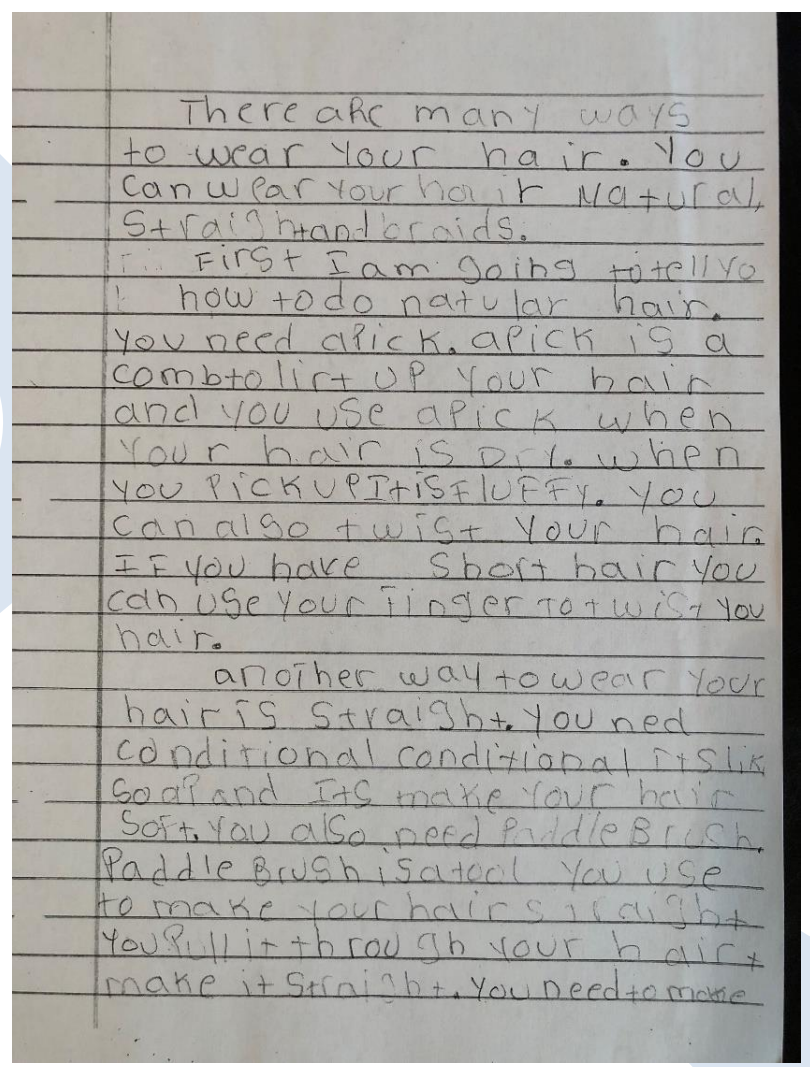

Figure 9 (a) 


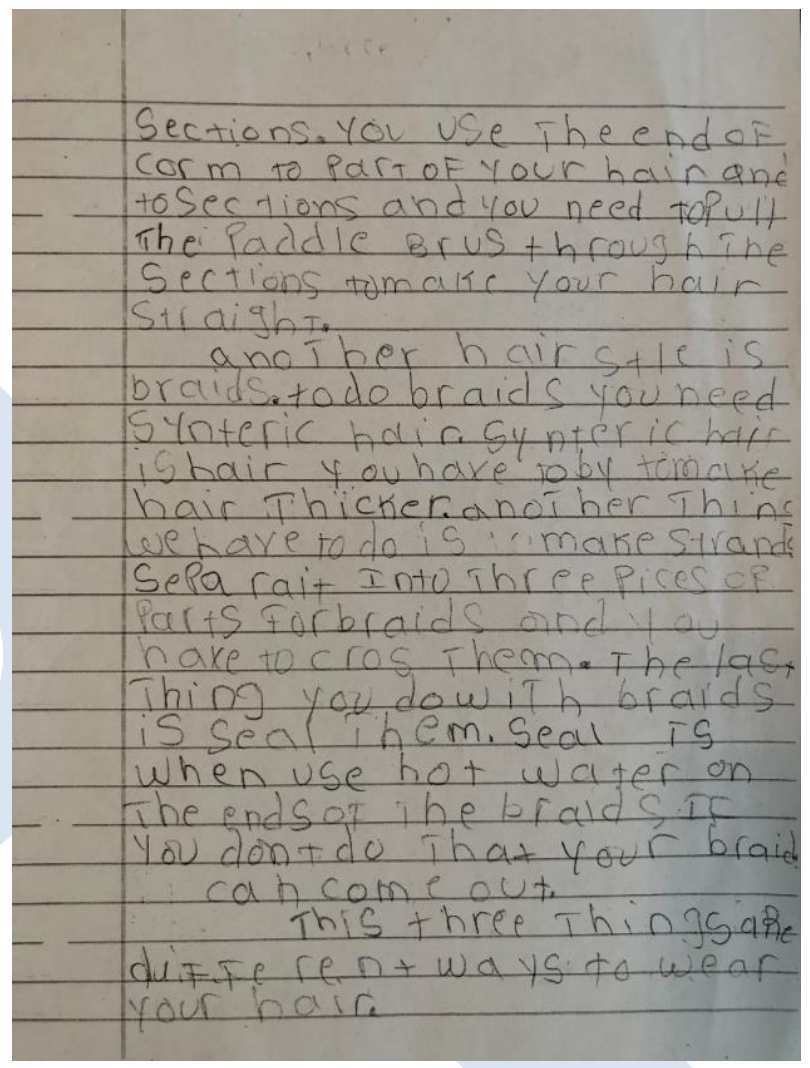

Figure 9 (b)

D.T.

D.T. is a 10-year-old English language with near native-like proficiency in reading and listening, however his productive language skills of speaking and writing are at the intermediate level of English proficiency. His native language is Spanish. He is in $5^{\text {th }}$ grade and has been in US schools and receiving instruction in English since Kindergarten. He communicates well in English with few errors when speaking. Because of his stronger English language skills, D.T. needed fewer supports than K.M. After I modeled the steps with 
his group, D.T. engaged in oral rehearsal with peers and teachers and developed his important ideas (Figure 10) and glossary words (Figure 11). The Expert Writing process with D.T. took place over three weeks with writing once or twice a week for 30 minutes at a time.

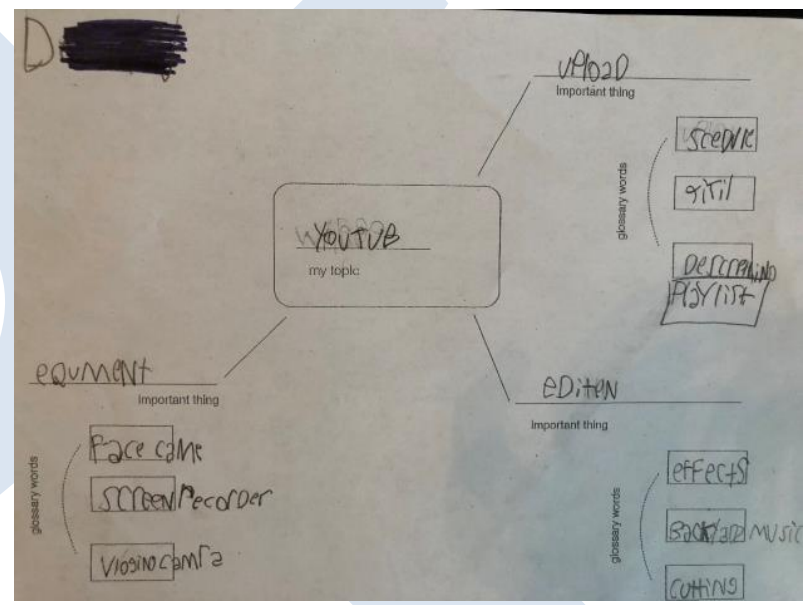

Figure 10 


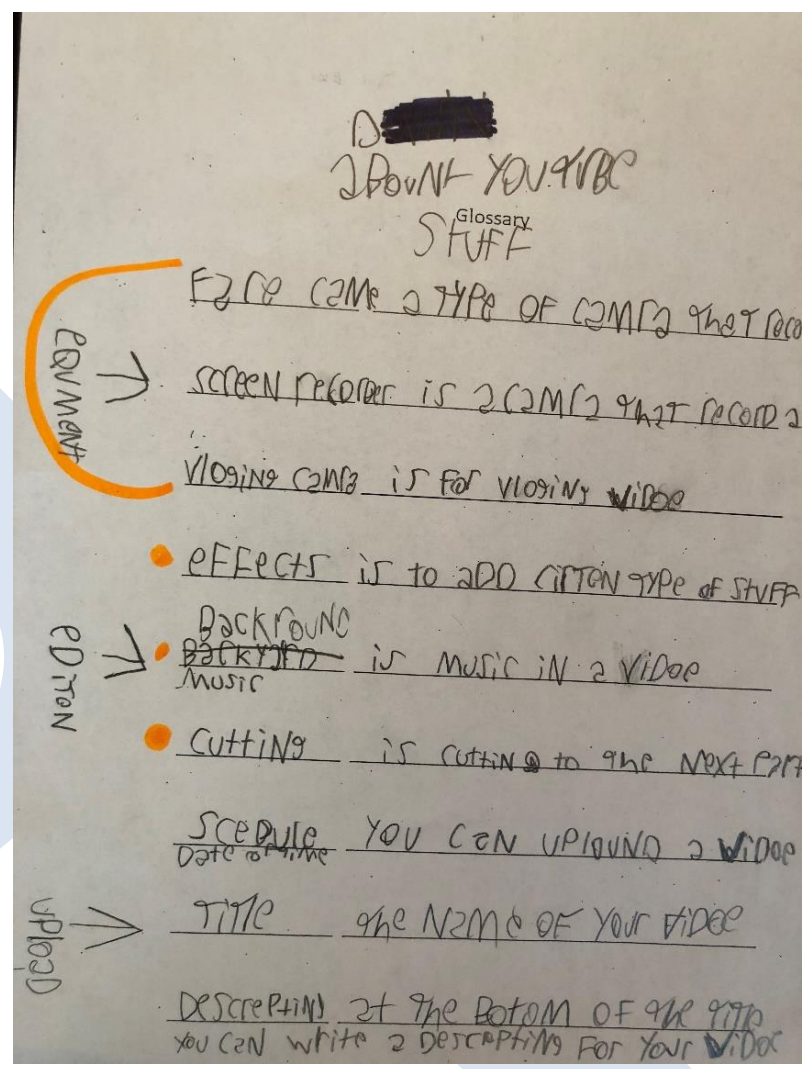

Figure 11

As he went through the steps in the Expert Writing process, D.T. made some adaptations himself. For example, he identified which glossary words went with which important ideas by annotating on his organizer (Figure 11). In addition, he labeled, each Partner Sentences graphic organizer with the corresponding important idea (Figure 12, Figure 13, and Figure 14). 


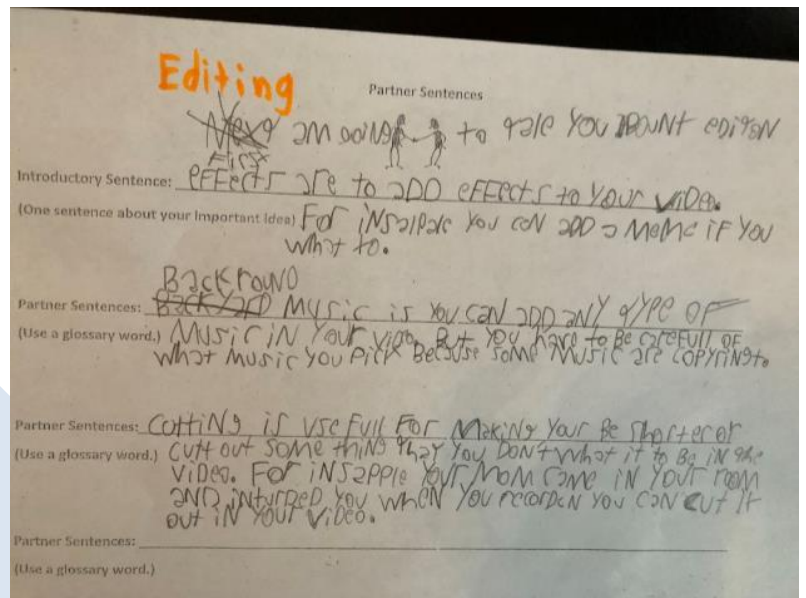

Figure 12
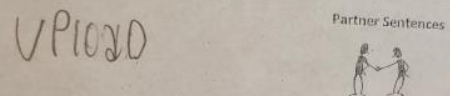

2 Nother in Porting ohing is UPlounding. UPlouNDis bour self.

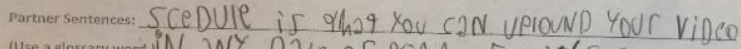
(Usea alossary word.) IN JNY OJte of YiMC. For iN SzPle Yod Whan't to uPlound J video 10 yedrs in the
Future You CRN Do Oha\%.

partner Sentences: rigle is a Name For your video. For insepe

(Use a glassary word.) if YOu WhoN't to NDMC your videe P $251+10$

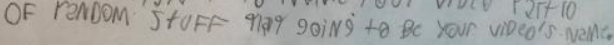

Partarer Sentences: The DescrePthing is a DescrePthivg For what Your

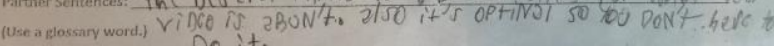

Figure 13 


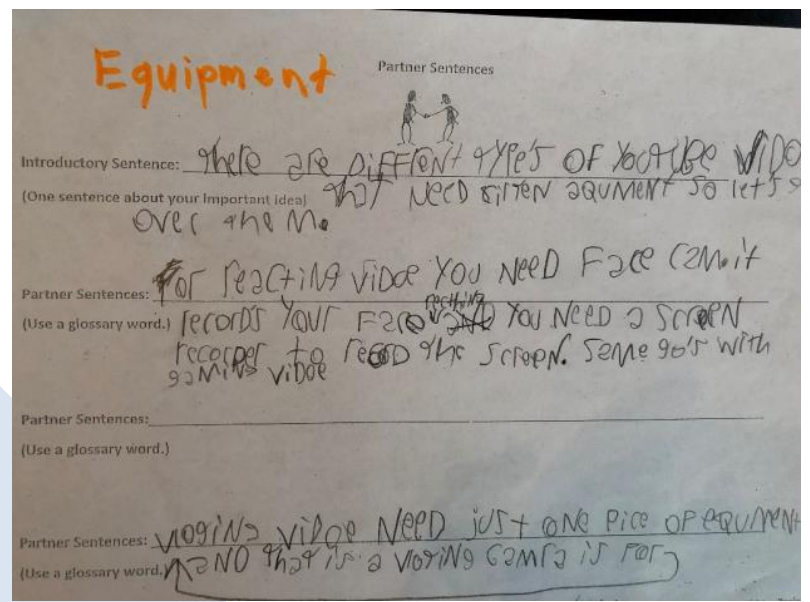

Figure 14

D.T. also added sentences when he wrote his draft rather than transferring his writing from his organizers directly to his draft. For example, in his draft, he added that "you can put likes to your websites or other videos in the description" (Figure 15 [a, b, c]), which was not on his organizer. He also elaborated on vlogging in his draft, adding: "For vlogging video you need just one piece of equipment and that is a vlogging camera." In addition, D.T. used subheadings in his draft, making each one of his important things a subhead. 


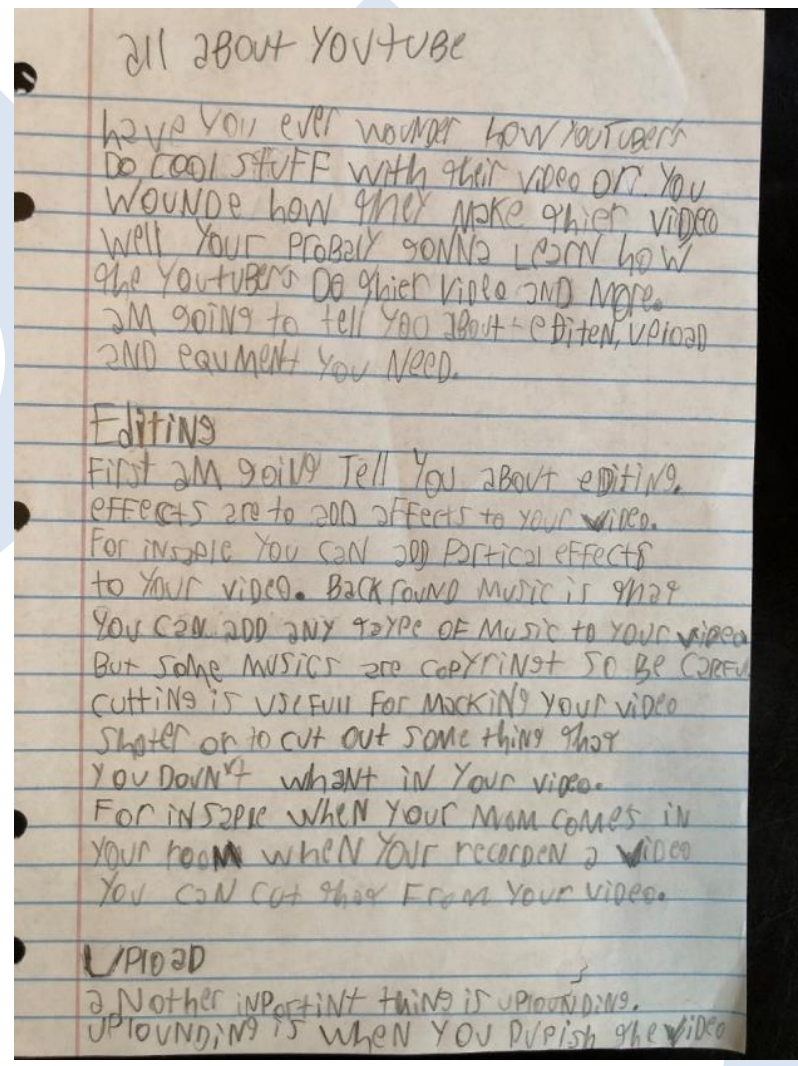

Figure 15 (a) 


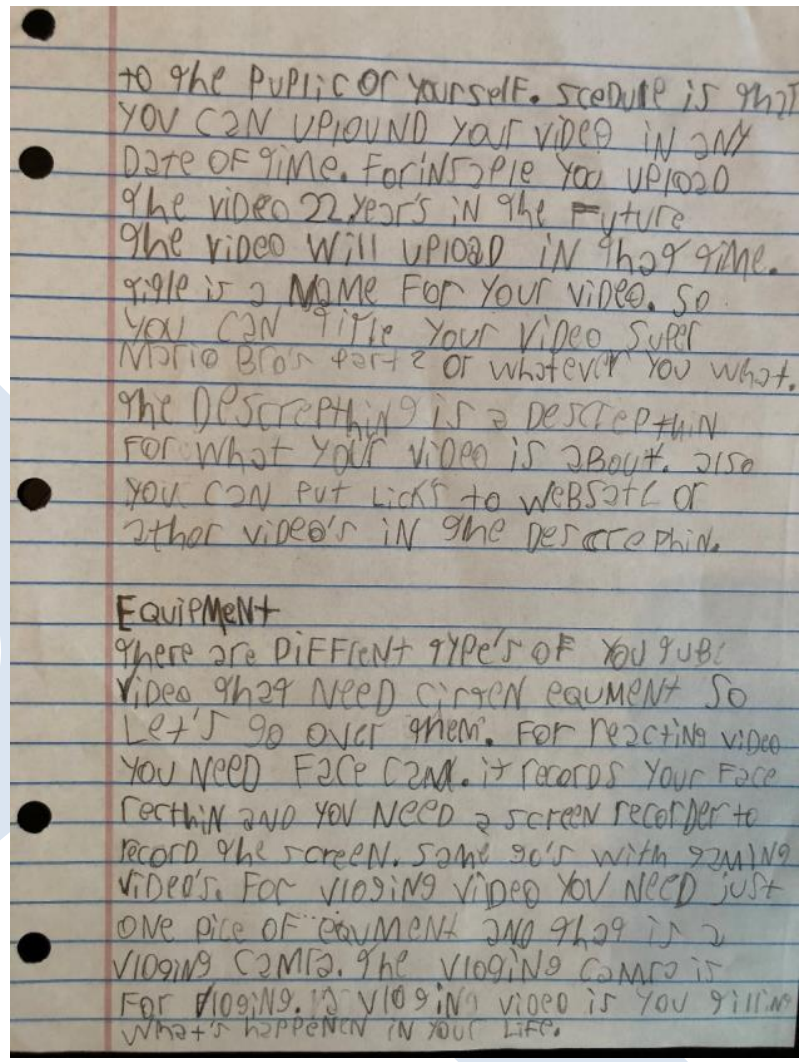

Figure 15 (b) 


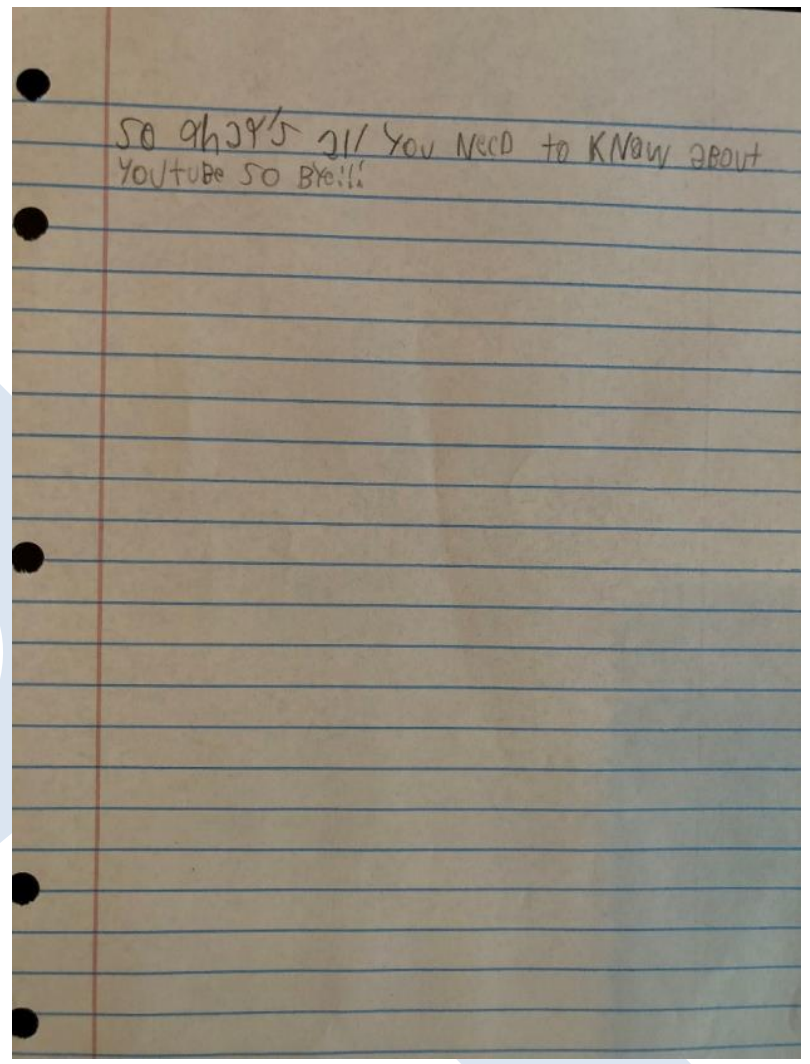

Figure 15 (c)

D.T.'s adaptations show that the Expert Writing can be flexible for students of higher language ability while K.M. adhered very closely to the scaffold. The organizers provide a scaffold that enables students of different levels of English language ability to organize an informational writing piece. When followed closely, students will produce a writing piece that is at least four paragraphs, with each paragraph containing seven sentences. The drafts produced can be revised to include transitions and additional details. Students can also be encouraged to do additional research to add details or to include text features such as pictures or illustrations. 


\section{A REDAÇÃO DE ESPECIALISTAS: ANÁLISE DA COMPOSIÇÃO DE TEXTOS INFORMATIVOS A PARTIR DE TEMAS FAMILIARES}

RESUMO: Este artigo descreve a "redação de especialistas", uma estratégia para apoiar aprendizes da língua inglesa e de outras línguas na organização e no desenvolvimento de ideias em redação informacional. Alunos do idioma inglês muitas vezes encontram dificuldades no desenvolvimento de ideias porque não têm vocabulário suficiente para construir frases e parágrafos expandidos. A "redação de especialistas" permite aos alunos elaborar esquemas sobre tópicos que eles já conhecem bem, a fim de desenvolver uma composição de texto informativo. Os alunos escolhem um tópico em que se consideram "especialistas" e depois "ensinam” o assunto aos colegas. Este exercício oral dá aos alunos uma audiência e encoraja-os a pensar sobre as dúvidas que um leitor pode ter sobre o assunto. Durante essa etapa, os alunos desenvolvem "ideias importantes" sobre o tópico, o que os ajuda a estruturar sua escrita, possibilitando-lhes desenvolver as ideias principais em parágrafos. Os alunos também criam "glossário de palavras", que é utilizado como um roteiro para a organização dos parágrafos em torno da ideia principal.

PALAVRAS-CHAVE: Aprendiz de língia inglesa; Desenvolvimento de ideias; Redação informativa; Exercício oral.

\section{REFERENCES}

CALKINS, L. The art of teaching writing. Portsmouth, NH: Heinemann, 1986.

CALKINS, L. If--then--curriculum: Assessment-based instruction, grade 4. Portsmouth, NH: Firsthand, an imprint of Heinemann, 2013.

FU, D. Writing between languages: How English language learners make the transition to fluency, grades 4-12. Portsmouth, NH: Heinemann, 2009.

FENNER, D.S. (2015, November 10). Writing with the Common Core: Considerations for ELLs (Part 1). Retrieved April 16, 2018, from http://www.colorincolorado.org/blog/writing-common-core-considerations-ells-part-1 


\section{Appendixes}

1-Important Things Graphic Organizer

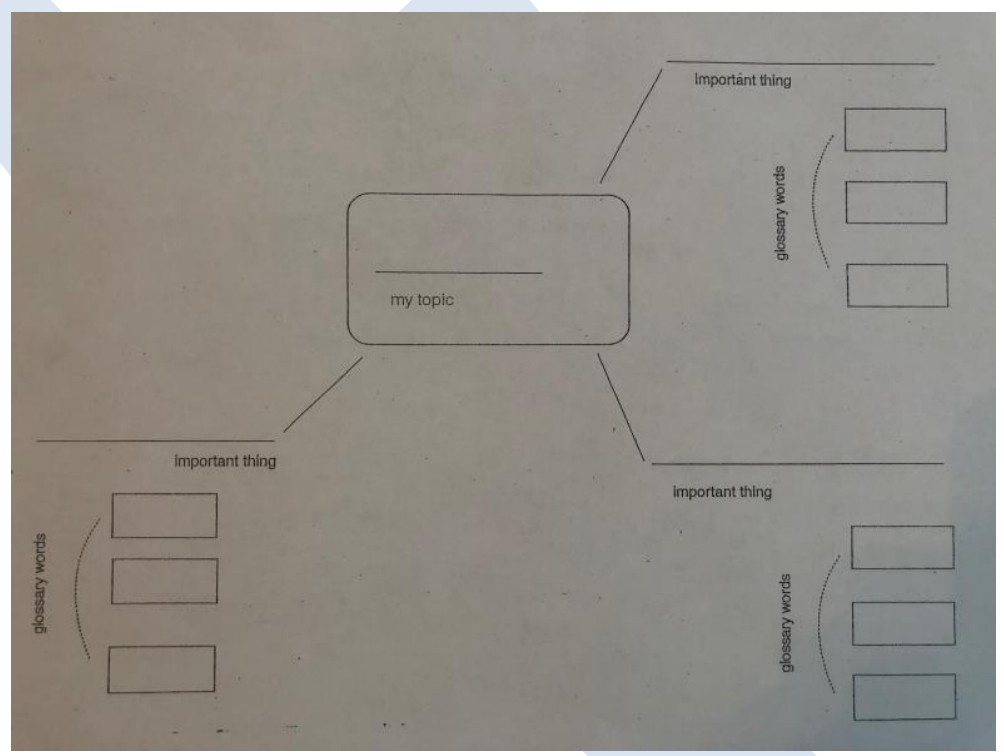




\section{2-Glossary Words Organizer}

Glossary

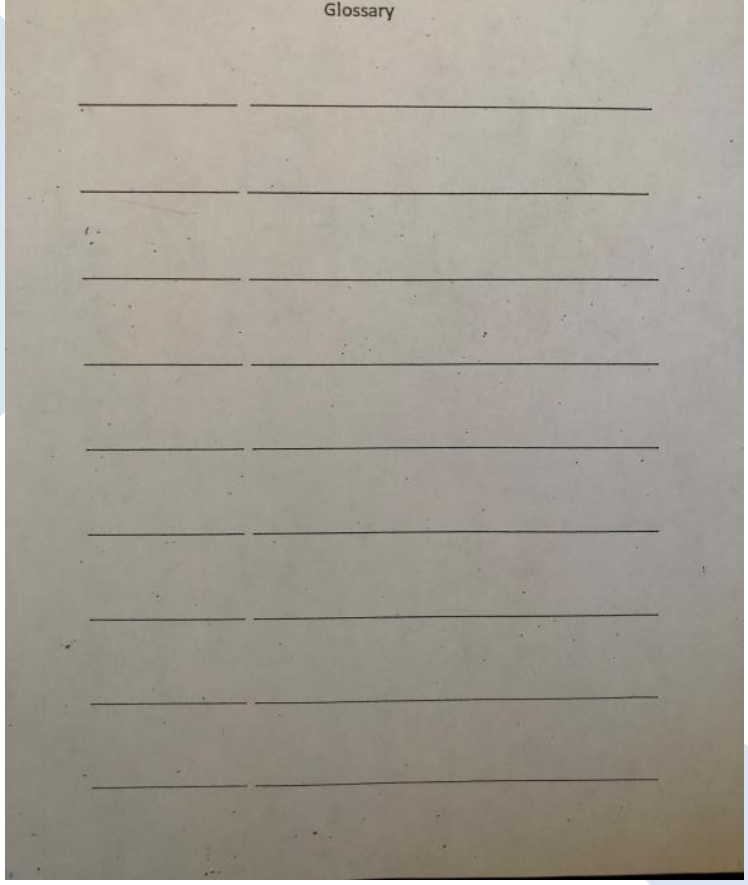




\section{3-Partner Sentences Graphic Organizer}

Introductory Sentence:

Partner Sentences

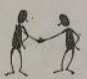

(One sentence about your important idea)

Partner Sentences:

(Use a glossary word.)

Partner Sentences:

(Use a glossary word.)

Partner Sentences:

(Use a glossary word.)

\section{4-Student drafts}

\section{Hairstyles}

(some misspellings have been corrected for clarity)

There are many ways to wear your hair. You can wear your hair natural, straight and braids. First, I'm going to tell you bow to do natural hair. You need a pick. A pick is a comb to lift up your hair and you use a pick. when your hair is dry. When you pick up, it is fluffy. You can also twist your hair. If you have short hair, you can use your finger to twist your hair.

Another way to wear your hair is straight. You need conditioner. Conditioner is like soap and it make your hair soft. You also need paddle brush. Paddle brush is a tool you use to make your hair straight. You pull it through your hair to make it straight. You need to make sections. You use the end of comb to part off your hair into sections and you need to pull the paddle brush through the sections to make your hair straight. 
Another hairstyle is braids. To do braids you need synthetic hair. Synthetic hair is hair you have to buy to make hair thicker. Another thing we have to do is make strands. Separait [sic] into three pieces or parts for braids and you have to cross them. The last thing you do with braids is seal them. Seal is when use hot water on the ends of the braids. If you don't do that, your braids can come out.

These three things are different ways to wear your hair.

\section{All About Youtube \\ (some misspellings have been corrected for clarity)}

Have you ever wondered how Youtubers do cool stuff with their video or you wondered how they make their video? Well, you're probably gonna learn how the Youtubers do their video and more. I am going to tell you about editing, upload, and equipment you need.

\section{Editing}

First I am going to tell you about editing. Effects are to add effects to your video. For example, you can add particle effects to your video. Background music is that you can add any type of music to your video but some of the musics are copyright do be careful. Cutting is useful for making your video shorter or to cut out something that you don't want in your video. For example when your mom comes in your room when you're recording a video you can cut that from yoru video.

\section{Upload}

Another important thing is uploading. Uploading is when you publish the video to the public or yourself. Schedule is that you can upload your video in any date of time. For example, you upload the video 22 years in the future the video will upload in that time. Title is a name for your video. So you can title your video Super Mario Bro's or whatever you want. The description is a description for what your video is about. Also, you can put likes to website or other videos in the description.

\section{Equipment}

There are different types of Youtube video that need certain equipment so let's go over them. For reacting video, you need a face cam. It records your face reaction and you need a screen recorder to record the screen. Same goes with gaming videos. For vlogging video you need just one piece of equipment and that is a vlogging camera. The vlogging camera is for vlogging. Vlogging video is you telling what's happening in your life.

So that's all you need to know about Youtube so Bye!! 